Original article

\title{
STRATEGIES FOR MANAGING GOVERNMENT SOVEREIGN WEALTH FUNDS DURING THE COVID-19 PANDEMIC
}

\author{
Mstislav P. Afanasiev' ${ }^{1}$ Nataliya N. Shash ${ }^{2}$ \\ ${ }^{1}$ National Research University Higher School of Economics, Moscow, Russia. \\ Institute of Economic Forecasting, Russian Academy of Sciences, Moscow, Russia. \\ E-mail: mstafan@hse.ru \\ ${ }^{2}$ Plekhanov Russian University of Economics. \\ The Financial Management Department. Moscow, Russia. \\ E-mail: SHash.NN@rea.ru
}

\begin{abstract}
This paper examines the transformational shifts in investment strategies of sovereign wealth funds. It analyzes the basic theory of sovereign wealth funds and justifies the need for its development. It identifies the similarities and distinguishing features of sovereign wealth funds. Four types of sovereign wealth funds are characterized, and the key requirements for their management system are clarified. Analysis results for the changing capital among the world's largest sovereign wealth funds since the start of the Covid-19 pandemic are given. Market value trends of the Government Pension Fund Global (Norway) for 1998-2021 were revealed, and a prediction of its changes for the period until 2026 was created. The influence of the Covid-19 epidemic on the structure of investment portfolios (including the emergence of a new class of assets) was presented, along with GPFG's investment strategy. Changes in the amount of NWF's funds (Russia) for the period 2008-2021 were presented and its growth for 2022-2023 was predicted. The transformation of NWF's liquidity regulatory structure was assessed. New trends in the investment activities of sovereign wealth funds, which occurred under the influence of the Covid-19 epidemic, were revealed. These include reduced risk appetite, increased investment activity, and a higher share of direct investments in asset portfolios. Individual sovereign wealth funds were used to compile a chart of their investment portfolios, which were diversified depending on investment goals and risk level. Recommendations for building the investment strategy of sovereign wealth funds were formulated, with a proposed algorithm for its formulation, including three consecutive stages. It is noted that the results of implementing the investment strategy of sovereign wealth funds directly depends on management quality, whose efficiency can be assessed using special indicators.
\end{abstract}


Keywords: sovereign wealth funds, counter-cyclical regulation, investment portfolio, investment tools, financial tools, financial assets, securities, investments resources, structure of liquid assets, investment strategies, investment horizon.

For citation: Afanasiev, M.P. and Shash, N.N. (2021) 'Strategies for managing government sovereign wealth funds during the Covid-19 pandemic', Public Administration Issues, 6 (Special Issue II, electronic edition), pp. 49-62 (in English). DOI: 10.17323/19995431-2021-0-6-49-62.

JEL Classification: E12, E20, E44, H62, F21, G11, G20, G23, H54, O16.

Covereign wealth funds first appeared in the 1950s (Kuwait, Venezuela), $\checkmark$ but it was only at the turn of the 21 st century on the backdrop of fairly high prices on primary commodities that countries with various levels of economic development (mainly, with a high share of revenue from hydrocarbon exports) began accumulating reserves, predominantly to stabilize government budgets and neutralize the devastating effects of crises. During this period, governments around the world began creating various kinds of sovereign wealth funds or fiscal surplus funds. The conditions of the Covid-19 pandemic, which led to increased macroeconomic stability and a decline in economic growth rates, gave sovereign wealth funds an additional push to grow.

\section{Sovereign wealth fund theory}

According to the most widespread approach, a sovereign wealth fund (SWF) is a specially formed fund whose accumulated resources can be channeled to balance the government budget in the event of increased revenue shortfalls and/or to carry out urgent activities to neutralize the macroeconomic shock felt in countries whose revenue significantly depends on the conditions of the world's commodity markets.

Thus, the classical understanding of a sovereign wealth fund is essentially an investment fund (predominantly government) ${ }^{1}$, whose asset portfolio includes government and corporate securities (bonds, stocks), investments in real estate projects and number of other financial tools, denominated in the major reserve currencies.

The theory of sovereign wealth funds was largely influenced by the Keynesian concept of counter-cyclical regulation, aimed at supporting the economic environment and stimulating economic growth rates during economic recessions.

In this context, sovereign wealth funds can be used as one of the most important tools of a government's counter-cyclical economic policy, within which accumulated resources can be channeled to achieve priority macroeconomic goals: financing deficit budget, stabilizing the national currency's exchange rate, stimulating investment activity, etc.

The authors' research shows that sovereign wealth funds created in various countries around the world not only have similar characteristics, but also display

\footnotetext{
1 Exceptions to this rule are, for example, China Investment Corporation (China) or Alaska Permanent Fund (USA).
} 
significant differences. Traditionally, four main types of sovereign wealth funds are identified depending on their intended purpose (Fig. 1).

\begin{tabular}{|c|c|c|}
\hline INTENDED PURPOSE & $\begin{array}{c}\text { SOVEREIGN WEALTH } \\
\text { FUND TYPE }\end{array}$ & \multicolumn{1}{|c|}{ EXAMPLES } \\
\hline $\begin{array}{c}\text { PROTECT AGAINST THE VOLATILITY } \\
\text { OF THE GLOBAL COMMODITY MARKETS } \\
\text { AND MACROECONOMIC SHOCKS }\end{array}$ & STABILIZATION & $\begin{array}{l}\text { NWF (Russian } \\
\text { Federation) } \\
\text { Copper Stabilization } \\
\text { Fund (Chile) }\end{array}$ \\
\hline $\begin{array}{c}\text { CONSERVE NATURAL RESOURCES FOR } \\
\text { FUTURE GENERATIONS IN CASE OF THEIR } \\
\text { EXHAUSTION }\end{array}$ & SAVINGS / RESERVE & $\begin{array}{l}\text { Fund Global, Norway } \\
\text { Government Pension }\end{array}$ \\
\hline $\begin{array}{c}\text { CARRY OUT LARGE INVESTMENT } \\
\text { PROJECTS INCLUDING INFRASTRUCTURAL }\end{array}$ & DEVELOPMENT & $\begin{array}{l}\text { China Investment } \\
\text { Corporation (China) }\end{array}$ \\
\hline $\begin{array}{c}\text { PRODUCE THE MAXIMUM AMOUNT } \\
\text { OF REVENUE FROM INVESTMENTS } \\
\text { IN RISKY ASSETS }\end{array}$ & INVESTMENT & $\begin{array}{l}\text { Government Investment } \\
\text { Corporation (Singapore) }\end{array}$ \\
\hline
\end{tabular}

Figure 1: Classification of the world's sovereign wealth funds ${ }^{\star}$

* Source: proposed by the authors based on material from the Sovereign Wealth Fund Institute (https://www.swfinstitute.org/); International Forum of Sovereign Wealth Funds (https://www. ifswf.org)

A number of traditional requirements exist for the system of managing sovereign wealth funds, which are still relevant in conditions of the new economic "normalcy":

- $\quad$ Produce the maximum level of revenue by forming an optimal structure for the investment portfolio.

- $\quad$ Ensure maximum transparency of investment activities.

- Comply with the established level of liquidity.

Questions related to the formation and operation of sovereign wealth funds are considered in the works of Allen, Caruana (2008); Balding (2008; 2012); Fernandez, Eschweiler (2008); Feng (2009); Levintal et al. (2009); Quadrio, Miceli (2010); Das, Mazarei, Hoorn (2010); Bolton, Samama, Stiglitz (2012); Castelli, Scacciavillani (2012); Clark, Dixon, Monk (2013); Bernstein, Lerner, Schoar (2013); Gelb, Tordo, Halland et al. (2014); Megliani (2015); Shemirani (2016); Rietveld, Toledano (2017); Leonov, Moiseev (2018); Alsweilem, Rietveld (2018); Braunstein (2019); Megginson, Gao (2020); and Ouni, Bernard, Plaisent (2020).

A growing interest in the role and activities of sovereign wealth funds has led to the need to build a corresponding theoretical foundation, which resulted in the establishment of the Sovereign Wealth Fund Institute (SWFI, 2007²) and the International Forum of Sovereign Wealth Funds (IFSWF, 2009³) in the early 2000s. Since their formation, these structures have published annual reports, which contain trends in the indicators of developing sovereign wealth funds around the world, summarize the experience of their activities and assess how efficiently assets are managed.

2 URL: https://www.swfinstitute.org/

3 URL: https://www.ifswf.org/ 
At the same time, issues of creating investment strategies and (moreso) evaluating how efficiently they are implemented remain beyond the scope of most research work dedicated to this subject.

Currently, there are more than 100 sovereign wealth funds in the world, whose growth is mainly due to increased wealth in developing countries and emergingmarket countries. More than $75 \%$ of SWF resources are concentrated in these countries with few exceptions (e.g., Norway, France ${ }^{4}$ ). Most of the resources were derived in the Middle East or Asia-Pacific region.

According to data from JP Morgan Asset Management, in 2020, the world's sovereign wealth funds owned assets amounting to $\$ 7.2$ trillion, double the corresponding indicator for 2007 and surpassing the total assets of all the world's hedge funds and private investment funds. Around $60 \%$ of the capital goes to sovereign wealth funds, which are formed by revenue generated from exporting energy carriers (revenue from hydrocarbons).

Currently, the ten largest sovereign wealth funds in terms of assets include those from Norway, China, Abu Dhabi, Saudi Arabia, Kuwait, Singapore and Qa$\operatorname{tar}$ (Fig. 2).

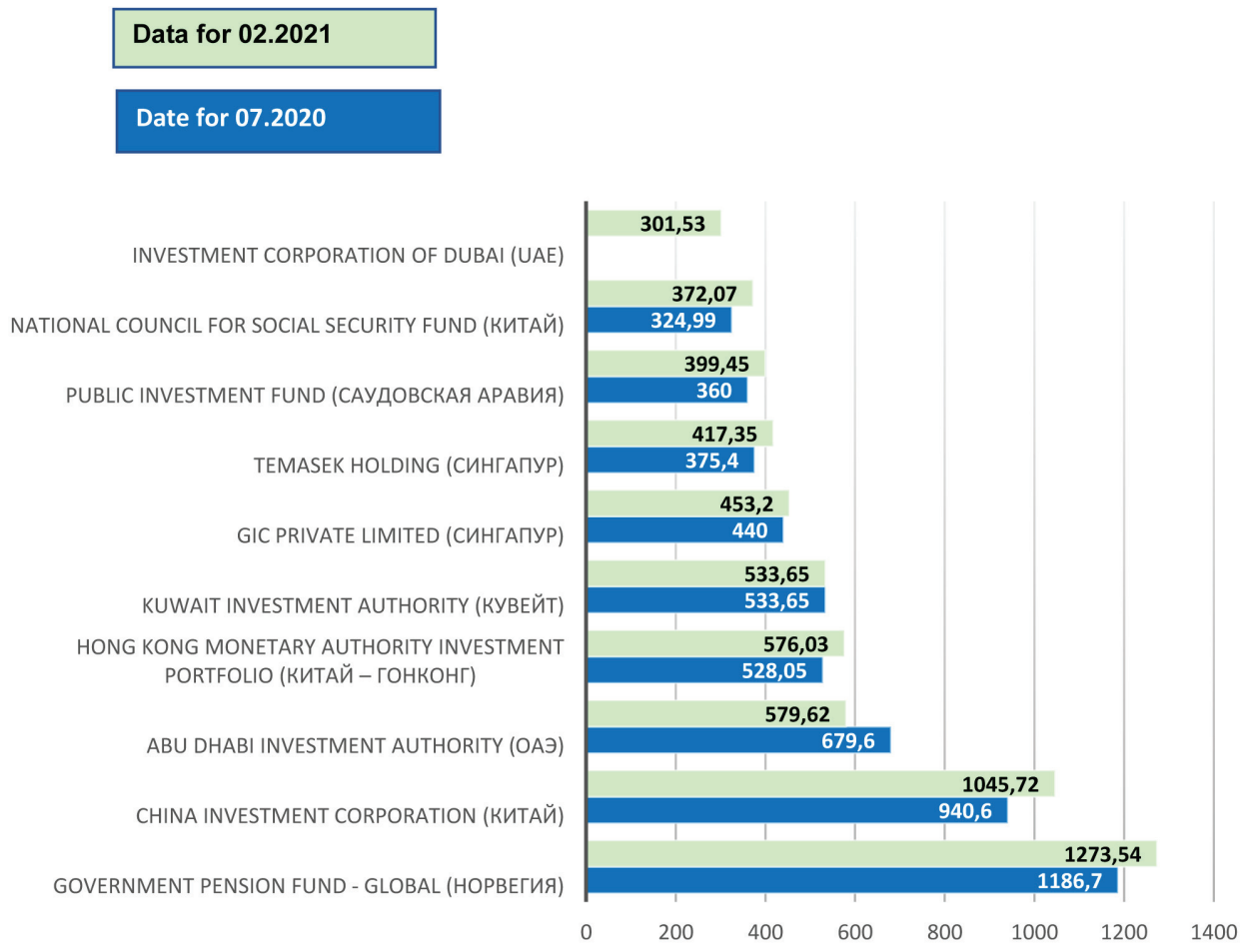

Figure 2: Leading Global Sovereign Wealth Funds (billion \$)*

The world's largest sovereign wealth funds (billion \$), based on data from 01.03.2021*

${ }^{\star}$ Source: based on data from: https://www.statista.com/statistics/276617/

\footnotetext{
${ }^{4}$ Bpifrance International Capital, formed in 2012, sovereign wealth fund of France and national investment bank. URL: https://www.bpifrance.com/
} 
The figure shows that over a seven-month period (July 2020 through February 2021) practically all global sovereign wealth funds (with the exception of Abu Dhabi Investment Authority (UAE), with a 15\% reduction) increased their assets.

The biggest growth was seen by China Investment Corporation (China) at over $11 \%$ and by the remaining leader of the ranking, Government Pension Fund Global (Norway), at almost 7.5\%. Out of the ten, a drop was seen by the 6th place holder, SAFE Investment Company (China), with assets of $\$ 417.8$ billion.

A newcomer to the ranking was the Investment Corporation of Dubai (UAE), whose assets in 2021 were estimated at $\$ 301.53$ billion.

\section{Market value trends and investment portfolio structure of Government Pension Fund Global (Norway)}

The world's largest Sovereign Wealth Fund (Government Pension Fund Global, GPFG) was formed at the end of the 20th century ${ }^{5}$ in order to invest in long-term additional funds assets, generated from exporting crude oil (as tax payments from the oil sector); earnings from the government-owned portfolio $^{6}$ of direct financial interest/state's direct financial interest (SDFI) by issuing licenses and permits for exploring and producing oil and natural gas on the Norwegian continental shelf; and dividends from government investments in the capital of the state company StatoilHydro, which patronizes all Norwegian business in the oil sector and in the area of hydropower.

The Norwegian oil fund was created in order to carry out responsible and long-term management of revenue from the kingdom's oil and gas resources in the North Sea to ensure a redistribution of wealth for future generations.

Over a 25-year period (1996-2020), the fund's market value grew from zero to $\$ 1275$ billion (Fig. 3 ). This is $11 \%$ more than the target projected value ( $\$ 1147.7$ billion).

It should be noted that more than half of GPFG's market value is made up of revenue created from the fund's investment activities. According to last year's results (2020), the Norwegian sovereign fund received investment earnings worth $\$ 122.7$ billion thanks to the significant price growth on existing assets in the portfolios of American tech giants (Apple, Amazon, Microsoft, Tesla), whose profitability neared $42 \%$.

Annual government investment makes up around one third. Another important source of income is that obtained by lending to corporations and countries.

GPFG's changing market value is influenced not only by the profitability of the investment tools used and the inflow and outflow of capital, but also by trends in the exchange rate of the Norwegian krone.

\footnotetext{
5 This fund was renamed in 2006 from its original name The Petroleum Fund of Norway.

6 Since 2001, portfolio management has been carried out by the Norwegian state company Petoro.
} 


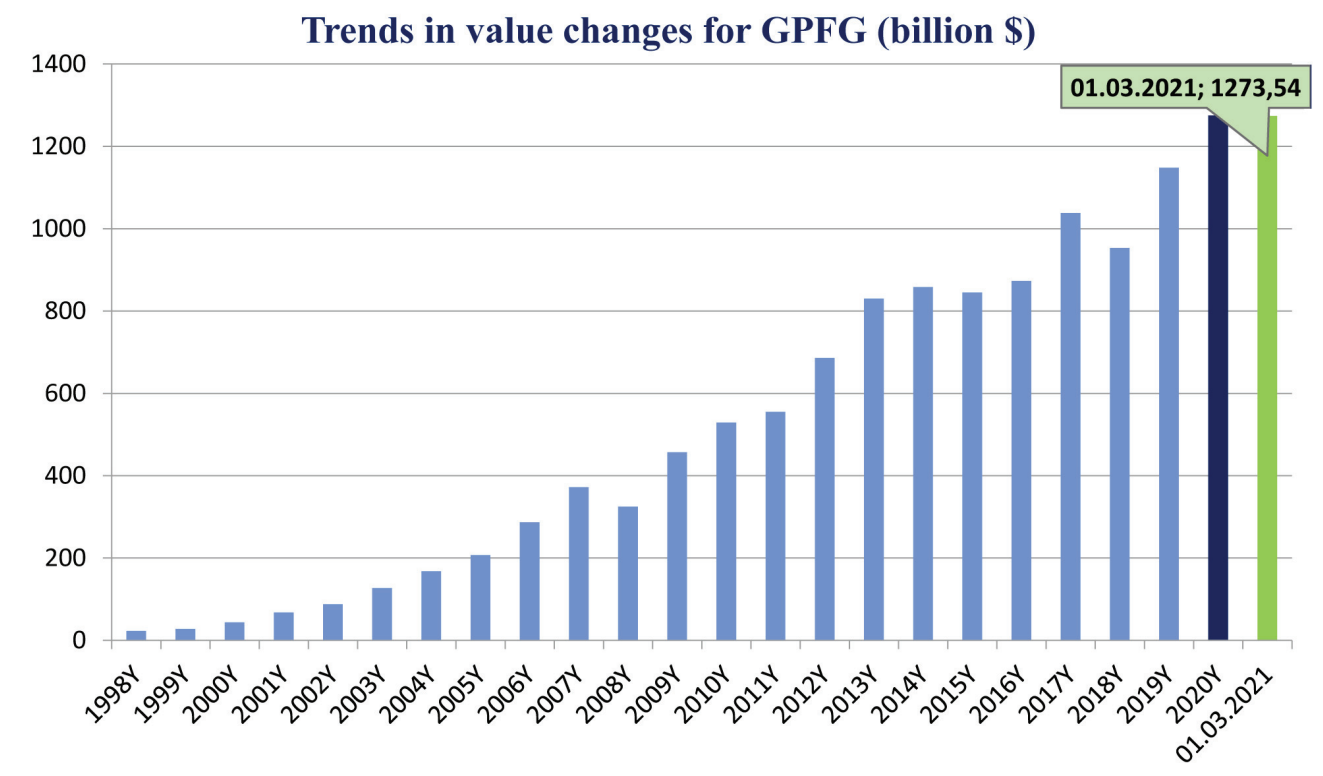

Figure 3: Trends in market value changes for Government Pension Fund Global (Norway), 1996-2020*

${ }^{\star}$ Source: based on data from: https://www.nbim.no/

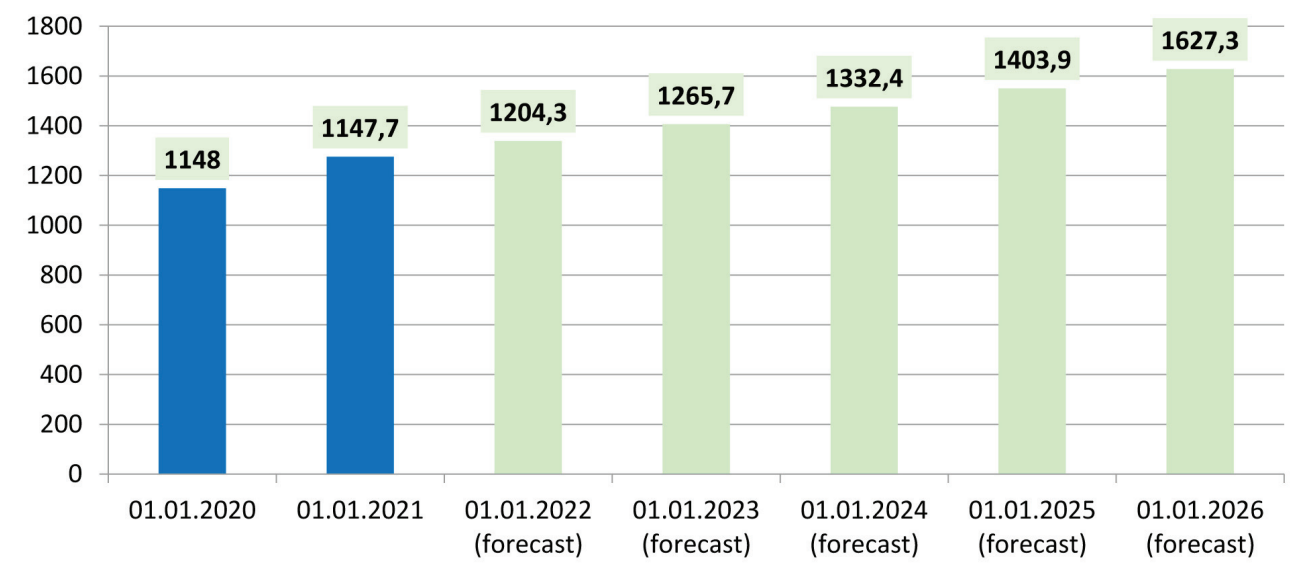

Figure 4: Forecast evaluations of market value changes for Government Pension Fund Global (2020-2026)*

${ }^{\star}$ Source: based on data from https://www.nbim.no/

The fund's general investment strategy, which is fixed in the Investment Mandate, is determined by the Ministry of Finance. GPFG's first investments in 1996 were derived from bonds. The investment portfolio was completed with assets. In recent years, an important area of investment has become real estate in New York, London and Paris.

In accordance with the authorized Investment Mandate, the Norges Bank Investment Management (NBIM), which covers GPFG funds, contributes investment 
resources to four main types of assets: equity investments, fixed-income investments $^{7}$, real estate investments, and infrastructure for renewable energy ${ }^{8}$ (Fig. 5).

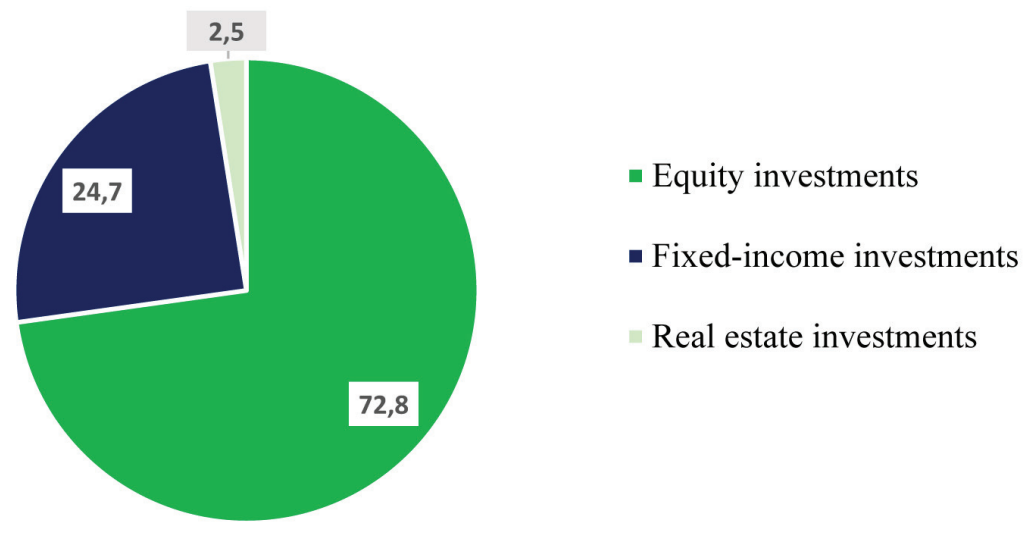

Figure 5: Structure of GPFG's investment portfolio as of 31.12.2020*

${ }^{*}$ Source: based on data from https://www.nbim.no/en/the-fund/holdings/

The global Norwegian fund traditionally invests in foreign assets to support a stable exchange rate of the national currency. GPFG's funds are distributed among 73 countries, including 9,123 companies around the world. The fund's portfolio makes up around $1.5 \%$ of all the world's assets. Since January 2020, investments in real estate have dropped from $6 \%$ to $2.5 \%$ and in bonds from $27 \%$ to $24.7 \%$. The number of investments in assets have increased from $67 \%$ to $72.8 \%$.

In 2020, the regulator (central bank of Norway (Norges Bank)), which is in charge of managing GPFG assets, made the strategic decision to withdraw resources invested in securities of large commodity companies around the world. In particular, there are plans to withdraw investments from corporations in three sectors: mining, electric power and oil production. This decision mainly concerns shareholdings of Sasol, RWE, Glencore', AGL Energy, Anglo American, Canadian Natural Resources, Cenovus Energy, Suncor Energy and Imperial Oil. This reflects the reorientation of the fund's investment activities to implement principles of responsible finance management (ESG).

\section{Total amount of assets and investment prospects of the Russian National Wealth Fund}

The Russian National Wealth Fund, whose capital is generated by income from a certain share of earnings from export operations with hydrocarbon raw

\footnotetext{
7 Fixed-income investments are distributed into bonds, issued by governments and government-associated institutions, and securities, issued by companies, while up to 30\% of GPFG can be invested in fixed capital.

8 In April 2021, 50\% of the Borssele 1\&2 offshore wind farms' capital (Netherlands) was purchased. This was the first time GPFG had invested in infrastructure for renewable energy sources.

9 For reference: at the end of 2019, the GPFG investment portfolio held $1.24 \%$ of Glencore shares, $2.4 \%$ of Anglo American and $0.6 \%$ of RWE.
} 
materials and income from investment activities, places 14th in the global ranking of the largest sovereign wealth funds. According to data by the Russian Ministry of Finance, the total amount of assets reached $\$ 187.57$ billion, which makes up $11.7 \%$ of the country's GDP (Fig. 5).

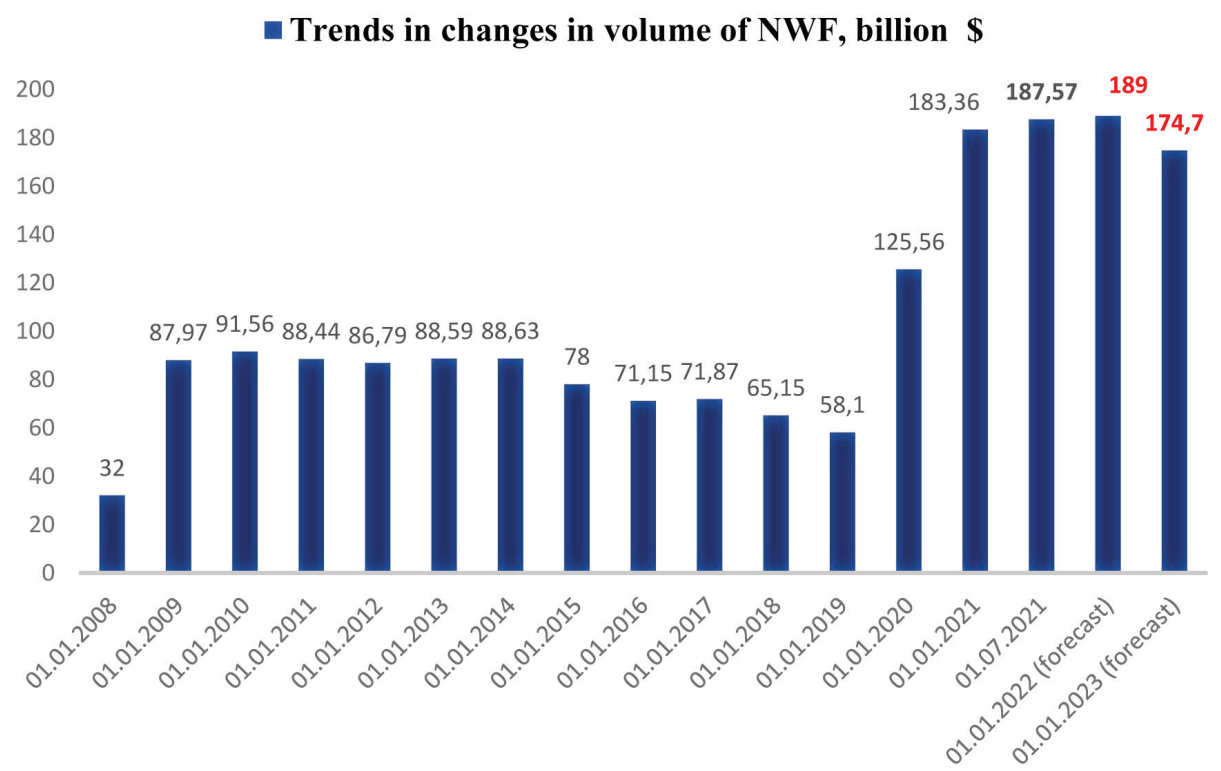

Figure 6: Trends in changes in volume of NWF in 2008-2025 (billion \$)

${ }^{\star}$ Source: based on data from https://minfin.gov.ru/ru/perfomance/nationalwealthfund/

Despite the existing economic slowdown, the growth of NWF assets in 2020 for the period from 01.01.2020 through 01.01.2021 equaled more than $46 \%$ (from $7.3 \%$ to $11.7 \%$ of the GDP).

To improve the efficiency of NWF activities, a new system for managing investment assets was introduced. This system:

- is aimed at increasing profitability from placing investment assets under the "budget rules" mechanism to support budget and financial sustainability in conditions of increased volatility of commodity markets.

- makes it possible to lower the level of budget and fiscal risks by forming a significant amount of liquid financial assets in the fund's financial portfolio to compensate shortfalls in budget revenue in the event of severe external stresses (such as the outbreak of the Covid-19 pandemic, or the tightening of sanctions in relation to budget-forming sectors of the national economy). In 2021, 91.1 billion rubles of NWF resources were used for urgent goals related to the need to compensate the forming deficit of oil and gas earnings in the revenue side of the budget. This included allocating 3.8 billion rubles of the sovereign wealth fund to co-financing the creation of pension savings for insured individuals, who paid additional insurance premiums for funded pensions. However, over the 2021 period, further growth of NWF assets is expected, which, given the exchange rate difference, will increase to $\$ 1.43$ billion. 
In the current year (2021), significant changes to the structure of liquid assets can be observed. These are related to its exclusion of the US dollar (Fig. 7).

\section{Regulatory structure of NWF liquid assets}

BEFORE 01.06.2021

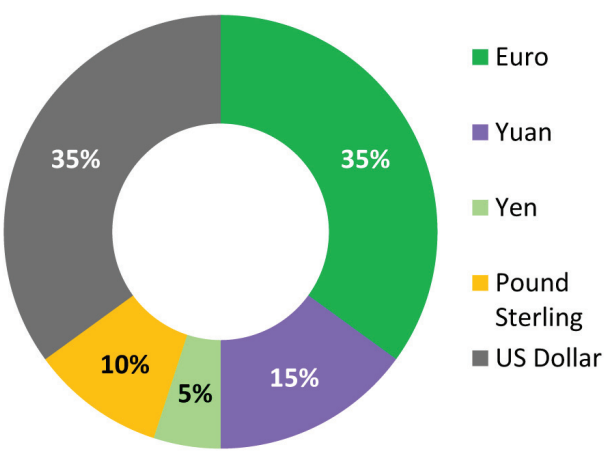

AFTER 01.06.2021

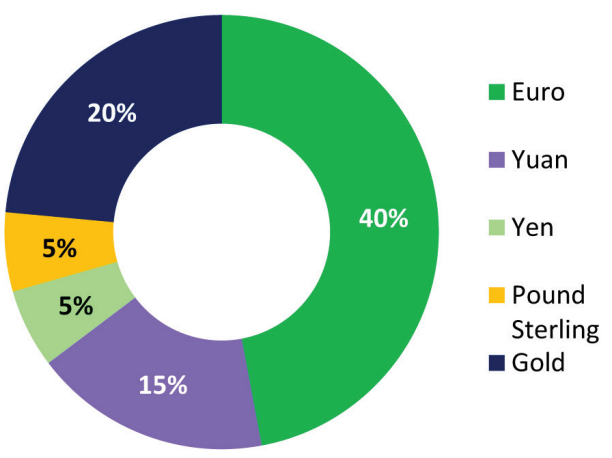

Figure 7: Transformation of regulatory structure of NWF liquid assets in $2021^{\star}$

${ }^{\star}$ Source: based on data by the Russian Ministry of Finance / https://minfin.gov.ru/ru/perfomance/ nationalwealthfund/

Another introduction has been the inclusion of liquid assets of gold (20\%) in the structure, which will be part of the fund's liquid assets in anonymized format (in the Central Bank of Russias metal accounts). This decision, which is evidence of the transition to a conservative investment strategy, was reasoned by the need to increase protection against inflation risks during an unstable global economy. Thus, the regulatory structure of the NWF liquidity and the structure of the Bank of Russia's international reserves continue to converge. At the same time, there are risks of significant adjustment on precious metal markets, the appearance of which can negatively affect the value of liquid assets.

Furthermore, there are currently discussions going on about introducing changes to the NWF investment strategy, particularly, about using funds for a) carrying out priority infrastructure projects, b) lending to certain countries, c) modernizing utility networks, and d) further increasing the amount of liquid assets by purchasing gold.

\section{Transformational shifts of SWF investment strategies}

Starting in 2010, sovereign wealth funds started actively investing in various financial and investment tools: corporate and government securities, real estate projects and investment funds. Stabilized funds are largely characterized by conservative management (since they perform functions of hedging budgetary commitments, ensuring maximum liquidity and preserving capital).

In connection with this, the investment portfolios of such SWF contain predominantly government treasury bonds of economically developed coun- 
tries (including those with a one-year maturity) and are placed in deposit accounts of highly reliable banking structures. National wealth and future generations funds, whose goal is to save funds from depreciating, use a wide range of financial (shares, corporate bonds) and alternative investment tools (real estate, venture capital investments, exchange traded funds (ETFs), primary commodities).

Currently, the majority of investments of sovereign wealth funds are made up of investments in corporate securities (55-60\%), while no more than 25\% goes to bonded debts and money market tools in general.

The available data suggests that in 2020 the number of assets invested by sovereign wealth funds in infrastructural projects increased, while their share in the investment portfolio structure decreased. Similarly, the share of real estate decreased significantly. This reflects the global long-term trend of reduced investment interest in "hard" assets.

Moreover, an analysis of the SWF investment structure showed the presence of a serious shift in the structure of their assets. One consequence of Covid-19 was the major shift in real estate investments: most funds replaced retail and office real estate for logistics real estate, whose share in investment portfolios grew from $15 \%$ to $22 \%$. The distribution of SWF resources across various investment areas is presented in Figure 8.

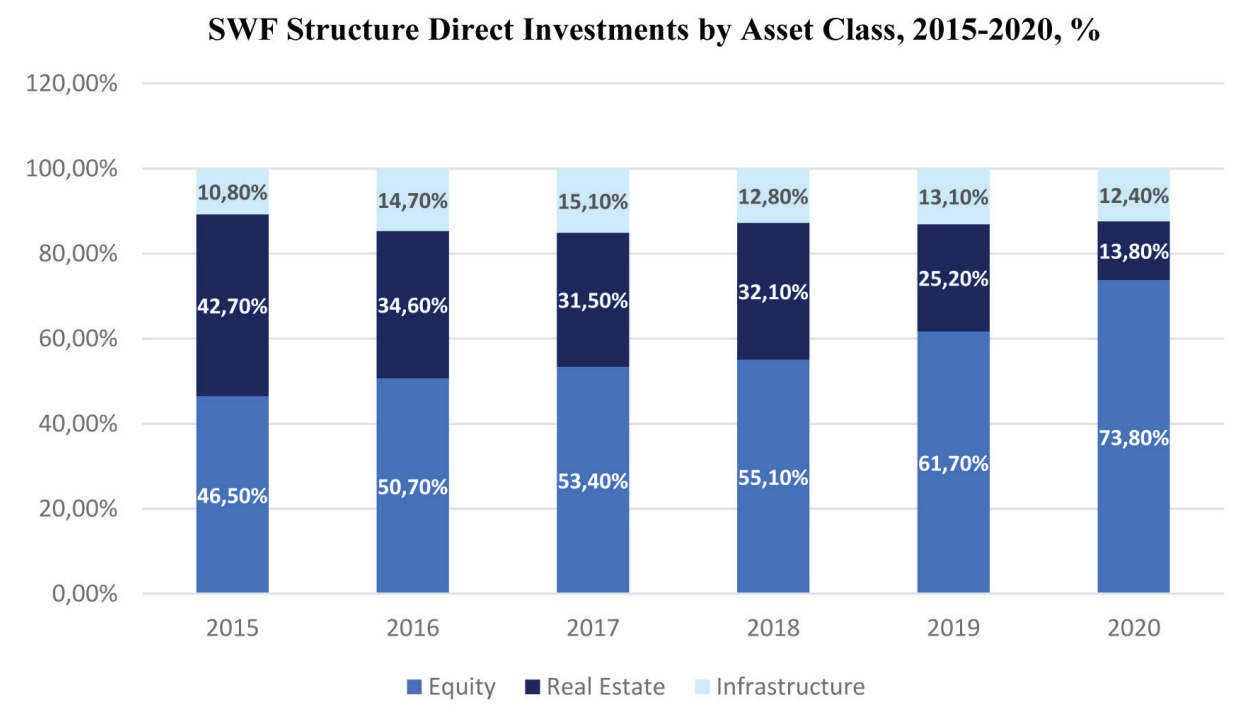

Figure 8. Trends in the SWF structure of direct investments by asset class, 2015-2020

${ }^{\star}$ Source: based on data from: https://ifswfreview.org/covid-response.html

Until 2020, SWF investment strategies were largely defensive in nature. In the pre-pandemic year (2019), their investment portfolio included the lowest amount of direct investments since the start of 2015 ( $\$ 35.9$ billion). Overall, 2020 resulted in it being one of the most active investment periods, during which the amount of SWF direct investments almost doubled from $\$ 35.9$ to $\$ 65.9$ billion (Fig. 9). 
SWF Direct Investments by Value 2015-2020, \$ bln

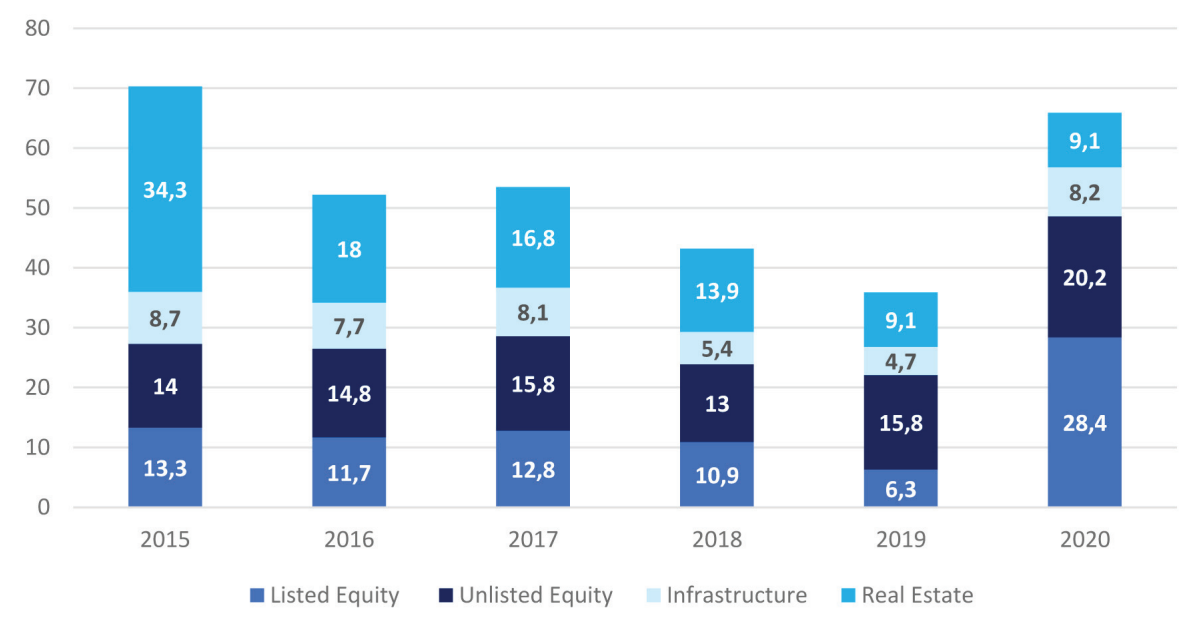

Fig. 9. Changes in value of total SWF investment assets for 2015-2020 (billion \$)*

${ }^{\star}$ Source: based on data from https://ifswfreview.org/covid-response.html

Impacted by the Covid-19 pandemic, new trends emerged in the investment activities of sovereign wealth funds. For the first time since they appeared, direct investments in 2020 (including strategic and hybrid) exceeded the overall savings funds (Figure 10).

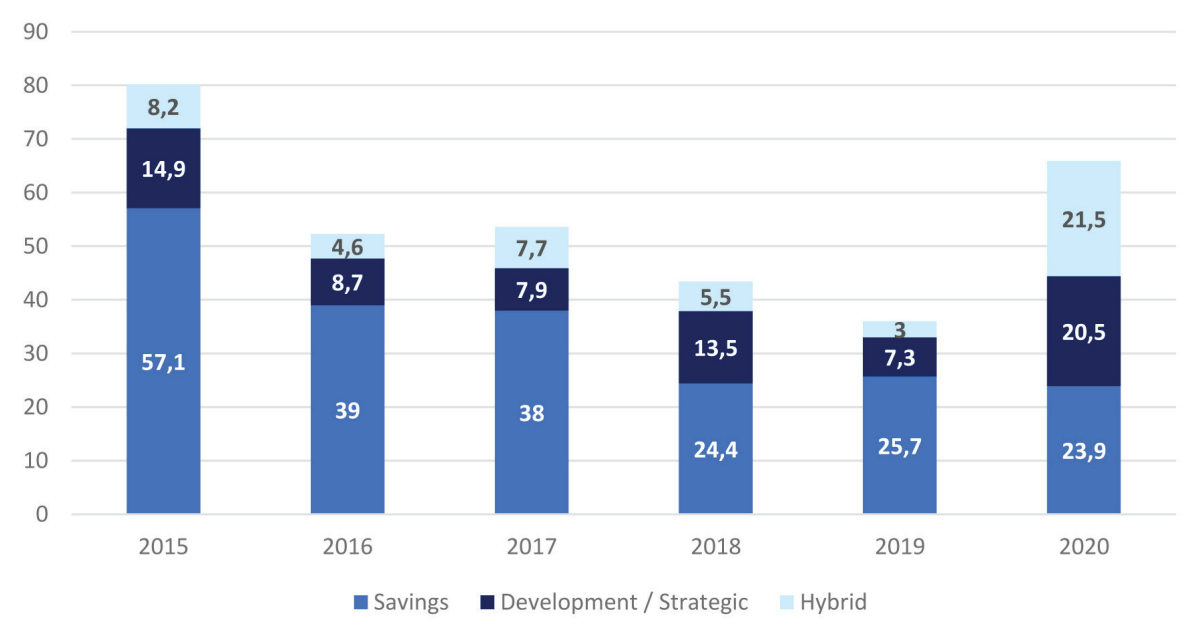

Figure 10: Ratio of savings, development/strategic, and hybrid investments of SWF 2015-2020, (billion \$)*

${ }^{\star}$ Source: based on data from: https://ifswfreview.org/covid-response.html

The emerging new trends in the investment activities of funds are of interest and reflect a significant reduction in their risk appetite. Since the start of 2020, SWF around the world have preferred to invest in less risky assets on sovereign debt markets, corporate bonds and foreign currencies, while the level of liquidity was at the highest observed since the global financial crisis. 
At the same time, the investment portfolios of various sovereign wealth funds are significantly diversified by risk level depending on the investment goals, determining the focus of the investment strategy (to support stability or increase profitability). According to this, a chart with the investment portfolios of sovereign wealth funds was compiled and is presented in Figure 11.

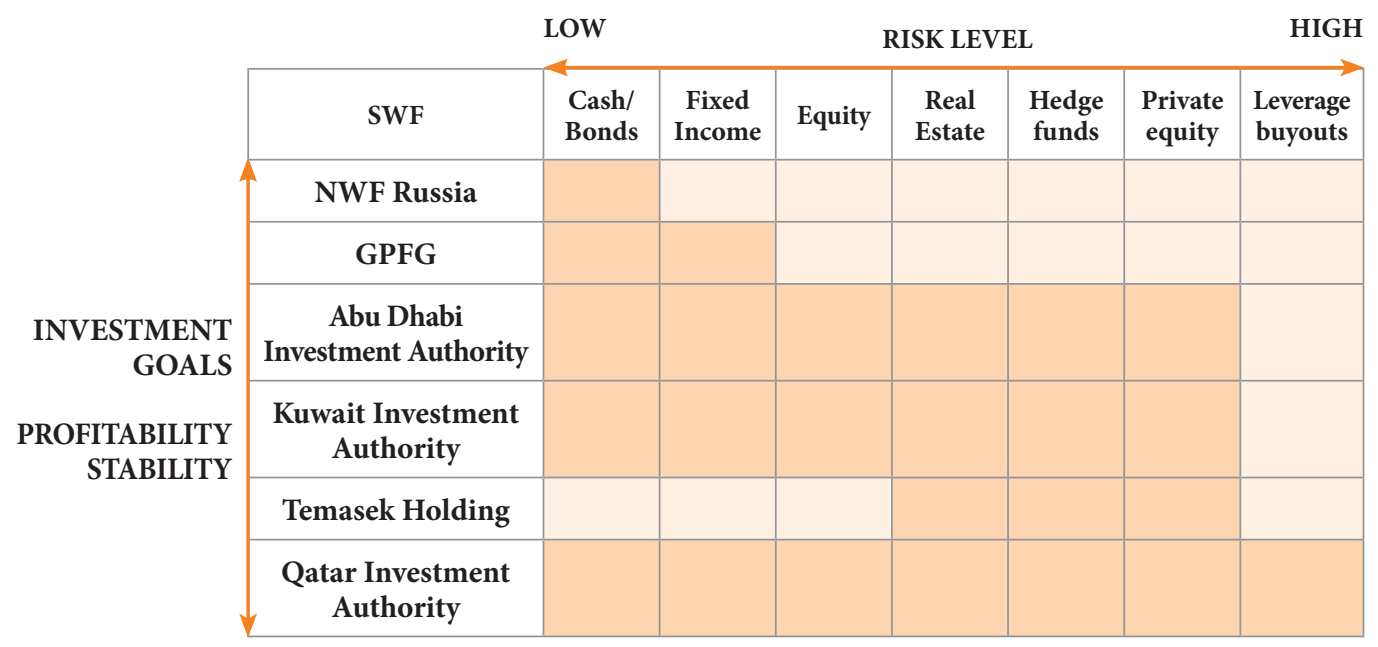

Figure 11: Chart of SWF investment portfolios according to investment goals and risk level for $2020^{*}$

${ }^{\star}$ Source: based on data from: https://ifswfreview.org

The new economic reality requires not only to make serious changes to the management strategies of sovereign wealth funds, but also to apply certain algorithms for their formation based on the established investment horizon. According to the authors, the process of creating an investment strategy should include the following three stages (Figure 12).

\section{CREATING AN SWF INVESTMENT STRATEGY}

STAGE 1:

STAGE 2:

STAGE 3:

DEVELOP
INVESTMENT
ACTIVITY PROFILE
formulate investment goals
determine amount
of investment resources
establish investment
benchmarks
confirm rules of carrying
out investment activities

CONFIRM OPTIMAL RATIO OF PROFITABILITY AND RISK

determine investment horizon

- establish profitability and risk levels

> select investment tools

\section{DEVELOP}

PRINCIPLES OF ASSET DIFFERENTIATION

$\checkmark$ select area of placement (countries, regions of the world)

$\checkmark$ determine investment timeline

- select currency for allocating assets

\section{Figure 12: Creating a SWF investment strategy ${ }^{\star}$}

${ }^{\star}$ Source: proposed by authors 
What a sovereign wealth fund's strategy contains depends directly on the investment horizon, which in turn is determined by the type of sovereign wealth fund (future generations fund: long-term, reserve; stabilized fund; short-term). When determining the investment horizon necessary to establish the desired level of profitability and an acceptable risk level, the following factors should be taken into consideration: 1) uneven revenue from implementing raw materials and the uncertainty of their supply and mining; 2) the need for sovereign wealth funds to complete previously unforeseen obligations (for example, due to a new pandemic).

In terms of an optimal investment portfolio, it should be a specific combination of various financial and investment tools for each sovereign fund, depending on the type (focus). For instance, the asset portfolio of SWF whose resources are formed mainly by revenue from exporting hydrocarbons, should include tools with a negative or minimally positive correlation with the movement of global commodity markets. In connection with this, in order to most effectively diversify the investment portfolio, the investment strategy of the sovereign wealth fund should be tied to macroeconomic forecasts, according to which a preliminary evaluation of the potential combination options of financial and investment assets needs to be taken after identifying the types of correlations.

In order to more efficiently manage investment risks, it is advisable for a fund to geographically diversify its portfolio, making the most use out of a range of tools available on the global financial markets.

The results of implementing the investment strategy of sovereign wealth funds directly depends on management quality, whose efficiency can be assessed using a combination of the following indicators:

- minimal profitability level of invested funds (rate of return);

- $\quad$ maximum duration of a fund's invested portfolio (bond duration);

- maximum risk indicator value in invested portfolio, due to investment decisions (tracking error);

- $\quad$ maximum possible loss in a specific period (value-at-risk models).

In order to increase efficient management of investment portfolios of sovereign wealth funds when they are formed, it is necessary to take into account new trends in their activities, which can include:

- increasing investment activity;

- constantly increasing share of direct investments in asset portfolios;

- creating global alliances of sovereign wealth funds when carrying out joint investment activities;

- $\quad$ investing resources into government support programs for priority sectors and economic sectors, including carrying out large-scale infrastructure projects.

\section{REFERENCES}

Allen, M. and Caruana, J. (2008) Sovereign wealth funds - A work agenda. IMF papers. Feb. 29. 
Alsweilem, K. and Rietveld, M. (2018) Sovereign wealth funds in resource economies: institutional and fiscal foundations. Columbia University Press. Available at: https:/doi.org/ $10.7312 /$ alsw18354

Balding, C. (2008) A portfolio analysis of sovereign wealth funds. HSBC School of Business; ESADE University Faculties - ESADEgeo.

Balding, C. (2012) Sovereign wealth funds: The new intersection of money and politics. Oxford Scholarship Online: May. DOI: 10.1093/ascrof:oso/9780199842902.001.0001.

Bernstein, S., Lerner, J. and Schoar, A. (2013) 'The investment strategies of sovereign wealth funds', Journal of Economic Perspectives, 27(2), pp. 219-238.

Bolton, P., Samama, F. and Stiglitz, J.E. (2012) Sovereign wealth funds and long-term investing. Columbia University Press, 288 p. Available at: https://doi.org/10.7312/bolt15862

Braunstein, J. (2019). Capital choices: Sectoral politics and the variation of sovereign wealth. University of Michigan Press, 312 p. Available at: https://doi.org/10.3998/mpub.9853048

Castelli, M. and Scacciavillani, F. (2012) The new economics of sovereign wealth funds. John Wiley \& Sons Ltd. 1st edition. 228 p. DOI:10.1002/9781119973478

Clark, G.L., Dixon, A.D. and Monk A.H.B. (2013) Sovereign wealth funds: Legitimacy, governance, and global power. Princeton University Press, 216 p.

Das, U. S., Mazarei, A. and van der Hoorn, H. (eds) (2010) Economics of sovereign wealth funds: Issues for policymakers. Washington, D.C.: International Monetary Fund.

Feng, Z. (2009) 'How Should Sovereign Wealth Funds Be Regulated?' Brooklyn Journal of Corporate, Financial \& Commercial Law, 3(2), article 7.

Fernandez, D.G. and Eschweiler, B. (2008) Sovereign wealth funds: A bottom-up primer. New York, J.P.: Morgan Research.

Gelb, A., Tordo, S., Halland, H. et al. (2014) Sovereign wealth funds and long-term development finance: Risks and opportunities. Policy Research Working Paper 6776.

Leonov, L.A. and Moiseev, A.K. (2018) 'The role of sovereign funds in stabilizing the world's financial architecture', Studies on Russian Economic Development, 29(1), pp. 56-61.

Levintal, O. et al. (2009) Financial crisis, equity capital and the liquidity trap. Interdisciplinary Center (IDC) Herzliyah February 26. DOI:10.2139/ssrn.1304548

Megginson, W.L. and Gao, X. (2020) 'The state of research on sovereign wealth funds', Global Finance Journal, 44, p. 100466. Available at: https://doi.org/10.1016/j.gf.2019.03.003

Megliani, M. (2015) Sovereign wealth funds and investment law. In: Finch N. (eds) Emerging Markets and Sovereign Risk. London: Palgrave Macmillan. Available at: https:// doi.org/10.1057/9781137450661_9

The article was submitted: 03.08.2021; approved after reviewing: 09.09.2021; accepted for publication: 28.11.2021. 